\title{
A Low Band Gap, Solution Processable Oligothiophene with a Diketopyrrolopyrrole Core for Use in Organic Solar Cells
}

\author{
Arnold B. Tamayo, Bright Walker, and Thuc-Quyen Nguyen* \\ Center for Polymers and Organic Solids and Department of Chemistry \& Biochemistry, \\ University of California, Santa Barbara, California 93106
}

Received: April 11, 2008

\begin{abstract}
We synthesized a low band gap, solution processable oligothiophene derivative functionalized with a diketopyrrolopyrrole core, which is a highly absorbing chromophoric group. This design leads to optical absorption that extends to $720 \mathrm{~nm}$ in solution and to $820 \mathrm{~nm}$ in the film. Cyclic voltammetry shows quasireversible oxidation and reduction processes. Bulk heterojunction solar cells using [6,6]-phenyl C61butyric acid methyl ester (PCBM) as the electron acceptor were fabricated. The power conversion efficiencies (PCEs) depend on the donor-acceptor ratio. A 70:30 donor/acceptor by weight mixture provided a PCE of $2.3 \%$ under simulated AM 1.5 solar irradiation of $100 \mathrm{~mW} / \mathrm{cm}^{2}$. To date, this is the highest efficiency reported for small molecule-based solution processed bulk heterojunction solar cells.
\end{abstract}

\section{Introduction}

Solar cells based on organic semiconductors are evolving into a promising cost-effective alternative to silicon-based solar cells due to low-cost fabrication by solution processing, ease of processing, lightweight, and compatibility with flexible substrates. ${ }^{1}$ Devices based on these materials are predicted to have an efficiency of $10 \%$ based on theoretical models. ${ }^{2}$ For instance, solution processed bulk heterojunction (BHJ) solar cells using poly(3-hexylthiophene) (P3HT) as the electron donor and [6,6]phenyl C61-butyric acid methyl ester (PCBM) as the electron acceptor have been reported to have efficiencies as high as $5.2 \%{ }^{3}$ Higher efficiencies are sought via research efforts focused on the design and synthesis of new donor and acceptor materials with high charge carrier mobility and strong absorption in the visible and near-infrared regions of the solar spectrum, ${ }^{4}$ as well as device processing, ${ }^{5}$ fabrication, ${ }^{6}$ and architecture design. ${ }^{7}$

Solution-processed solar cells based on conjugated small molecule donors and fullerene acceptors have also been investigated by a number of research groups. To date, small molecule based solar cell devices have power conversion efficiencies ranging from $0.3 \%$ to $1.3 \% .{ }^{8-16}$ These efficiencies remain low when compared to either thermally deposited small molecule bilayer solar cells ${ }^{17}$ or polymer-based solar cells. ${ }^{3,5}$ Despite the lower performance attained thus far, conjugated small molecules can potentially offer several advantages over polymeric materials making them promising materials for solution-processed solar cells. For example, molecular organic semiconductors, such as oligothiophenes and oligoacenes, display higher hole and electron mobilities than their polymeric analogues as a result of better molecular ordering. Most important, conjugated small molecules do not suffer from batch to batch variations, broad molecular weight distributions, end group contamination, and difficult purification methods, as is the situation for their polymeric counterparts.

Unlike their polymeric analogues, thiophene-based oligomers have not been fully investigated as donor materials in solar cells. Although they exhibit high charge carrier mobilities in organic field-effect transistors (OFETs), which can also be a critical parameter in organic solar cells, they do not absorb strongly in the red and near-infrared part of the solar spectrum where most photons are concentrated. Excellent overlap between the absorption of the semiconducting material and the terrestrial solar spectrum is a key requirement for increasing solar cell efficiencies. Another reason that oligothiophenes have not been as readily incorporated into solution processed devices is their low solubility in common organic solvents, as a result of strong intermolecular $\pi-\pi$ interactions. To make oligothiophenes that exhibit absorption at long wavelengths, electron donors (e.g., arylamines) and acceptors (e.g., cyano, benzothiadiazole) have been appended onto their backbone. ${ }^{12,15,17 a, 18}$ The addition of these groups changes the redox properties of the materials and thereby their absorption properties. The same donor-acceptor approach has been used to create low band gap fluorene copolymers that exhibit intramolecular charge transfer absorption at long wavelengths. ${ }^{19}$ To make oligothiophenes that can be solution processed, a variety of functional groups have been incorporated as side chains such as charged groups, ${ }^{20}$ acyl groups, ${ }^{21}$ alkylsulfanyl groups, ${ }^{22}$ alkylsilyl groups, ${ }^{23}$ ether-based dendrons, ${ }^{24}$ and straight and branched alkyl moieties. ${ }^{25}$ Other approaches include attaching solubilizing groups that can be thermally removed after film deposition ${ }^{26}$ and to partially disrupt the strong intermolecular $\pi-\pi$ interactions by designing starshaped or cross-shaped systems..$^{27,28}$

One potential strategy to make suitable donor materials using oligothiophenes is to incorporate highly absorbing chromophores that are used to make dyes and pigments. One such chromophore is 3,6-diaryl-2,5-dihydro-pyrrolo[3,4-c]pyrrole-1,4-dione or more commonly known as diketopyrrolopyrrole (DPP). ${ }^{29}$ DPPcontaining materials are bright and strongly fluorescent with exceptional photochemical, mechanical, and thermal stability and are therefore used in industrial applications as highperformance pigments in paints, plastics, and inks. ${ }^{30}$ DPP-based molecular materials, however, are not soluble in most common organic solvents due to the concurrent strong $\mathrm{H}$-bonding and $\pi-\pi$ intermolecular interactions in the solid state. ${ }^{31}$ Soluble derivatives, however, can be made by attaching solubilizing groups including ionic groups,${ }^{32}$ charged, ${ }^{33}$ or neutral long alkyl chains, ${ }^{34,35}$ and organic protecting groups such as $t$-Boc ${ }^{36}$ on the 3,4-positions (i.e., the lactam $\mathrm{N}$ atoms) and/or on the 2,5positions of the DPP moiety. It has been shown that the solid 

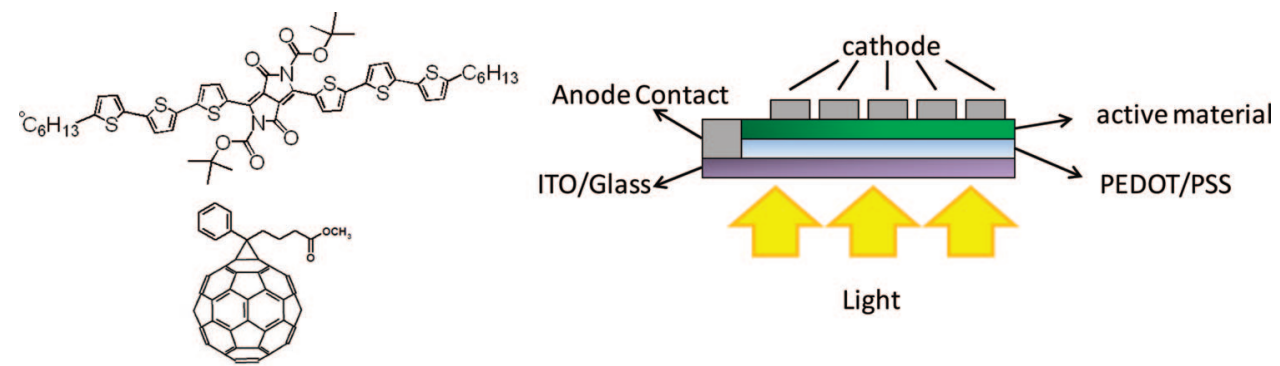

Figure 1. Schematic device structure and chemical structures of compounds used to fabricate the BHJ $\alpha, \alpha-D H 6$ TDPP:PCBM solar cell.

state packing and optical properties of DPP containing materials are dependent on the nature of these substituents..$^{33,34,37}$ Recently, we have shown that DPP-containing oligothiophenes selfassemble in the solid state forming unexpected nanostructures. The self-assembly process can be controlled by the number of thiophene rings and the nature of the aliphatic chains attached to $\mathrm{N}$ atoms. ${ }^{35}$

In light of this research, we now report the synthesis of an oligothiophene derivative suitable for solution-processed small molecule-based BHJ solar cells consisting of a diketopyrrolopyrrole chromophoric unit with $t$-Boc groups on the $N, N$ positions and terthiophene units attached to the 2 and 5-positions (compound $\alpha, \alpha$-DH6TDPP in Figure 1). This system was designed to take advantage of (1) the highly absorbing and the electron accepting ${ }^{38}$ ability of the DPP moiety whose solubility and electronic properties can be tuned by varying the substituents on the nitrogen atoms, (2) the hole transporting and electron donating properties of oligothiophenes, (3) the extended absorption at long wavelengths due to intramolecular charge transfer between the thiophene units and the DPP core, and (4) the molecular ordering of oligothiophenes and DPP-based materials in the solid state which can potentially lead to enhanced charge carrier mobilities.

\section{Experimental Section}

Density Functional Theory (DFT). DFT calculations were performed using the Titan software package (Wavefunction, Inc.) at the B3LYP/6-31G** level. The highest occupied molecular orbital (HOMO) and lowest unoccupied molecular orbital (LUMO) energies were determined using minimized singlet geometries to approximate the ground state.

Electrochemical and Photophysical Characterization. Cyclic voltammetry (CV) was performed using an EG\&G potentiostat/galvanostat model 283. Anhydrous dichloromethane was used as the solvent under an inert atmosphere, and $0.1 \mathrm{M}$ solution tetra-butyl ammonium hexafluorophosphate was used as the supporting electrolyte. A glassy carbon rod was used as the working electrode, a platinum wire was used as the counter electrode, and a silver wire was used as a pseudo reference electrode. The redox potentials are obtained by taking the average of anodic and cathodic waves and are reported relative to a ferrocenium/ferrocene $\left(\mathrm{Cp}_{2} \mathrm{Fe}^{+} / \mathrm{Cp}_{2} \mathrm{Fe}, 0.475 \mathrm{~V}\right.$ versus $\mathrm{SCE}$ in dichloromethane) redox couple used as an internal reference. ${ }^{39}$ UV-visible absorption spectra were recorded on a Shimadzu UV-2401 PC dual beam spectrometer. Steady-state fluorescence experiments at room temperature were performed using a PT1 (Lawrenceville, NJ) Quantum Master fluorometer equipped with a Xenon lamp excitation source and a Hamamatsu (Japan) 928 PMT using $90^{\circ}$ angle detection for solution samples.

Film Morphology. Tapping mode atomic force microscopy (AFM) topographic and phase images of pure $\alpha, \alpha-D H 6 T D P P$ and the blends were obtained using the Multi-Mode microscope and the controller NanoScope IIIa (Veeco Inc.). Images were collected in air using silicon probes with a typical spring constant of $1-5 \mathrm{nN} / \mathrm{m}$ and a resonant frequency of $75 \mathrm{kHz}$ (Budget Sensors).

Device Fabrication and Characterization. Indium tin oxide (ITO)-coated glass substrates (Thin Film Devices) were cleaned with detergent and deionized water after which the substrates were sonicated for 10 min in soap solution, deionized water, acetone, and isopropanol. The ITO substrates were then treated in a UV ozone cleaner for $30 \mathrm{~min}$ followed by spin coating a solution of poly(3,4-ethylene dioxythiophene/poly(styrenesulfonate) (PEDOT:PSS, Baytron P) (5000 rpm for $40 \mathrm{~s}$ ). The PEDOT:PSS film was dried at $140{ }^{\circ} \mathrm{C}$ inside a glovebox for 15 min which yielded a film of $\sim 40 \mathrm{~nm}$ thick. A $2 \%(\mathrm{w} / \mathrm{v})$ blend solution of $\alpha, \alpha$-DH6TDPP and PCBM (Nano-C, USA) in chloroform $\left(\mathrm{CHCl}_{3}\right)$ was filtered through a $0.45 \mu \mathrm{m}$ poly(tetrafluoroethylene) (PTFE) filter and spin coated at $1500 \mathrm{rpm}$ for $60 \mathrm{~s}$ on top of the PEDOT:PSS layer. Subsequently, aluminum $(1200 \AA)$ was thermally evaporated at a pressure of $1 \times 10^{-7}$ Torr at room temperature using a shadow mask. Illumination was done through the glass slide using light from $150 \mathrm{~W}$ Newport-Oriel AM 1.5G light source operating at $100 \mathrm{~mW} /$ $\mathrm{cm}^{2}$. Mobility measurements were done using the following diode structures: ITO/PEDOT:PSS/active material/Au for holes and $\mathrm{Al} /$ active material/Al for electrons. The charge carrier mobilities were calculated using the space-charge limited current (SCLC) model. ${ }^{40} \mathrm{Au}(1000 \AA)$ and Al (500 ̊) electrodes were thermally evaporated at a pressure of $1 \times 10^{-7}$ Torr at room temperature using a shadow mask (Angstrom Engineering, Inc.). The active layer thicknesses in all devices obtained by AFM were approximately $100-110 \mathrm{~nm}$. Current versus voltage curves $(I-V)$ characteristics were measured with a Keithley 2602 Digital Source Meter. All fabrications and characterization were performed under nitrogen.

\section{Results and Discussion}

Physical Properties and Film Morphology of $\alpha, \alpha-$ DH6TDPP. Figure 1 gives the device schematic and chemical structures of the donor material $\boldsymbol{\alpha}, \boldsymbol{\alpha}$-DH6TDPP and the acceptor material PCBM used to fabricate the bulk heterojunction solar cells. The detailed synthesis and characterization of the donor material is given in the Supporting Information. The geometry and electronic structure of $\boldsymbol{\alpha}, \boldsymbol{\alpha}$-DH6TDPP were examined at the $a b$ initio density functional level with the Titan software package. Becke's three parameter gradient corrected functional (B3LYP) with a polarized $6-31 \mathrm{G}^{* *}$ basis was used for full geometry optimization. $\mathrm{H}$ atoms were used in place of the $n$-hexyl groups to limit computation time. The geometry and the HOMO and the LUMO surface plots of the ground-state optimized structures are illustrated in Figure 2. The HOMO contains both oligothiophene and DPP character, whereas the LUMO is located predominantly on the DPP core. The 


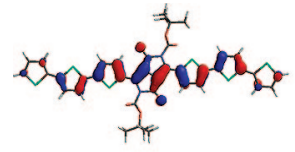

HOMO

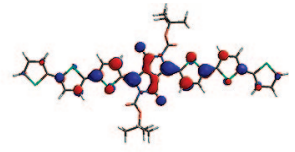

LUMO
Figure 2. HOMO and LUMO surface plots for $\alpha, \alpha$-DH6TDPP.

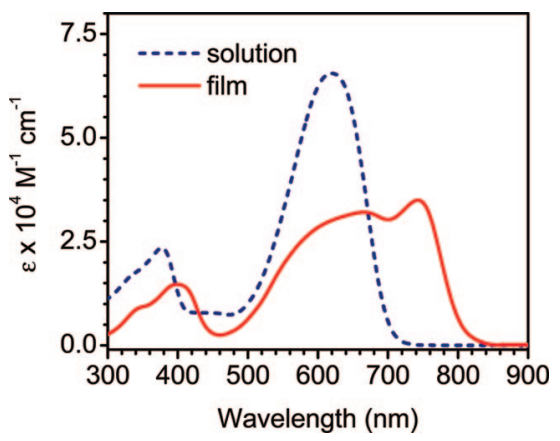

Figure 3. Solution and film absorption of $\alpha, \alpha$-DH6TDPP in chloroform and on a quartz substrate.

calculated HOMO and LUMO energies of the ground-state optimized geometry of $\boldsymbol{\alpha}, \boldsymbol{\alpha}$-DH6TDPP are $-4.73 \mathrm{eV}$ and -2.83 $\mathrm{eV}$, respectively. The difference between the ground HOMO and LUMO was then used to estimate the singlet energy gap which was calculated to be $190 \mathrm{eV}(\lambda=653 \mathrm{~nm})$. This value is in agreement with the values obtained from both the electrochemical and optical measurements for $\boldsymbol{\alpha}, \boldsymbol{\alpha}$-DH6TDPP, $\Delta E_{1 / 2}{ }^{\text {redox }}=2.04 \mathrm{~V}$ and $\Delta E_{\text {opt }}=2.01 \mathrm{eV}(\lambda=616 \mathrm{~nm})$ (vide infra), with some margin of error. The results of the DFT calculations will be discussed as they pertain to the interpretation of electrochemical and spectroscopy results.

The electrochemistry of $\boldsymbol{\alpha}, \boldsymbol{\alpha}$-DH6TDPP in anhydrous dichloromethane was examined using $\mathrm{CV}$ measurements in the presence of tetrabutylammonium hexafluorophosphate as a supporting electrolyte. The redox potential for $\alpha, \alpha$-DH6TDPP was measured relative to ferrocene $\left(\mathrm{Cp}_{2} \mathrm{Fe}^{+} / \mathrm{Cp}_{2} \mathrm{Fe}=4.6 \mathrm{eV}\right)$, which was used as the internal reference. The CV of $\alpha, \alpha-$ DH6TDPP exhibits one reversible oxidation process and one reduction process at $0.43 \mathrm{~V}$ and at $-1.61 \mathrm{~V}$, respectively. Based on the measured oxidation and reduction potentials, $\alpha, \alpha$ DH6TDPP has HOMO and LUMO energy levels of -5.03 and $-3.0 \mathrm{eV}$, respectively. The DFT calculated HOMO and LUMO

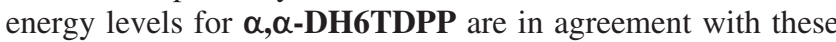
values. These values are also within the required electronic levels for BHJ solar cells when PCBM is used as the electron acceptor. ${ }^{2}$ Furthermore, it can be envisioned based on the DFT results that other derivatives of $\boldsymbol{\alpha}, \boldsymbol{\alpha}$-DH6TDPP can be made with modified HOMO and LUMO levels by varying the substituents at the 2,5 and/or 3,4 positions.

Figure 3 shows a plot of the solution and film absorption spectra of $\alpha, \alpha$-DH6TDPP in chloroform and on quartz, respectively. The high degree of conjugation between the electron donating thiophene rings and the electron accepting DPP moiety, as predicted by DFT calculations, is demonstrated in solution where the compound shows a broad and featureless absorption band with a $\lambda_{\max }=616 \mathrm{~nm}$ corresponding to the intramolecular charge transfer (ICT) transition. This absorption band is bathochromically shifted relative to the $\pi-\pi^{*}$ transitions in water-soluble sexithiophenes, which occur between 400 and $500 \mathrm{~nm}$ in dilute solutions. ${ }^{20}$ The film absorption of pure $\boldsymbol{\alpha}, \boldsymbol{\alpha}$ DH6TDPP on a quartz substrate spin-coated from a $2 \%(\mathrm{w} / \mathrm{v})$ chloroform solution is significantly broadened and exhibits two absorption bands centered at 660 and $742 \mathrm{~nm}$. These peaks are
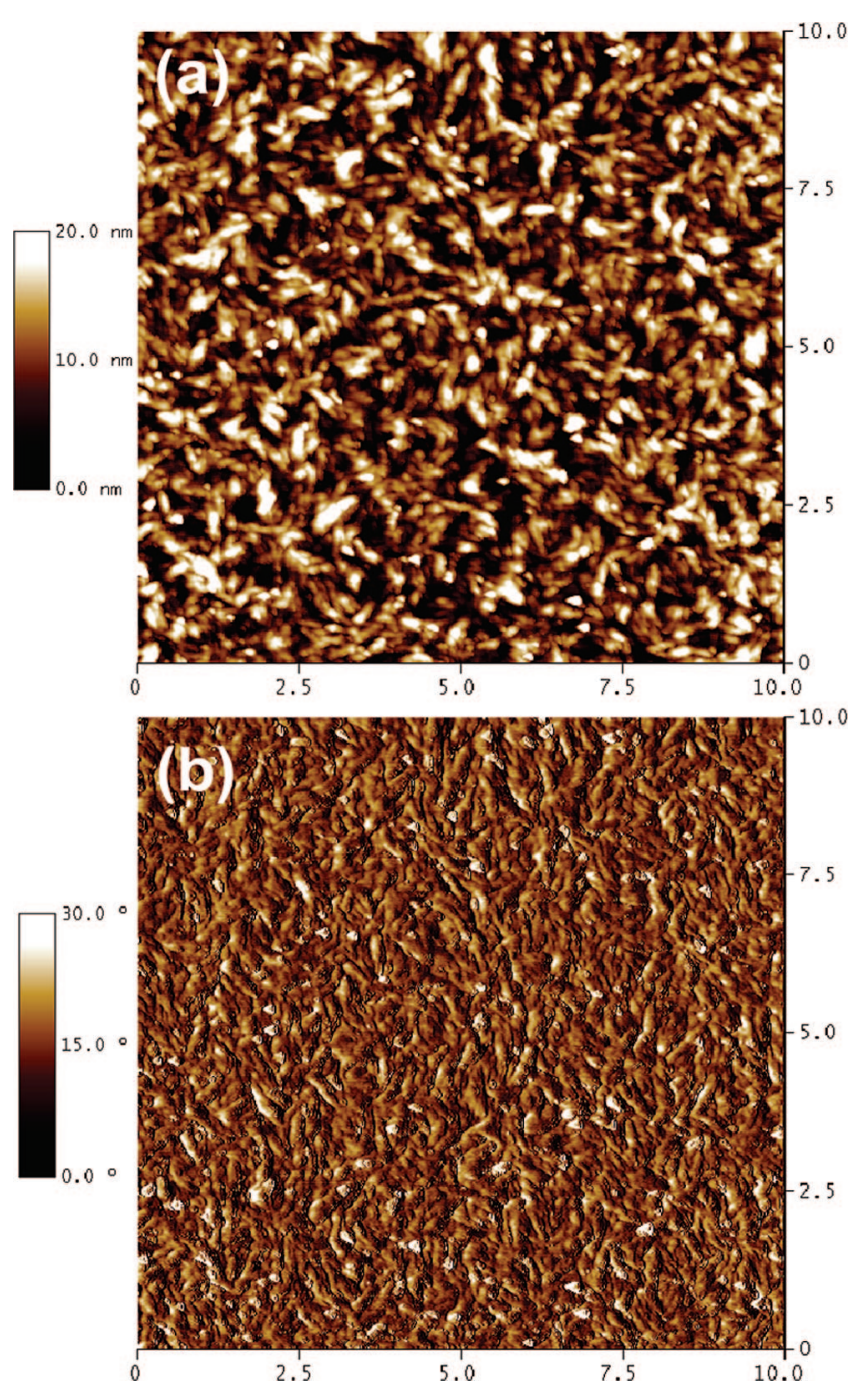

Figure 4. Tapping mode AFM $(10 \mu \mathrm{m} \times 10 \mu \mathrm{m})$ topographical (a) and phase (b) images of pristine $\alpha, \alpha$-DH6TDPP film spin-coated from chloroform on a quartz substrate.

44 and $126 \mathrm{~nm}$ red-shifted from the main absorption band observed in solution, respectively. The first absorption band is quite broad and is likely due to the same charge transfer band seen in solution and the shift in the peak maximum is due to aggregation in the solid state. The second sharp absorption band is possibly due to ordered aggregation, which is confirmed by AFM (see Figure 4). The absorption band edge of the compound is shifted from $1.72 \mathrm{eV}$ in solution to $1.51 \mathrm{eV}$ in film. One reason for this significant change might be the coplanarization of the thiophene rings due to molecular ordering, similar to what has been observed for spin-coated films of thiophene oligomers and polymers.

Figure 4 shows the topographic and phase images of $\alpha, \alpha$ DH6TDPP spin-coated from $\mathrm{CHCl}_{3}$ onto a quartz substrate. Fiber-like structures are observed in the topographic and phase images indicating a high degree of molecular order. The hole mobility, $\mu_{\mathrm{h}}$, of $\boldsymbol{\alpha}, \boldsymbol{\alpha}$-DH6TDPP was measured to be $3 \times 10^{-6}$ $\mathrm{cm}^{2} / \mathrm{V} \cdot \mathrm{s}$ using the ITO/ $\alpha, \alpha-D H 6$ TDPP/Au diode configuration. This value is comparable with hole mobilities measured for small molecules (i.e., $\sim 10^{-6} \mathrm{~cm}^{2} / \mathrm{V} \cdot \mathrm{s}$, for triphenylamine derivatives $)^{16}$ and conjugated polymers that are used as electron donors for solar cells (i.e., $\sim 10^{-7} \mathrm{~cm}^{2} / \mathrm{V} \cdot \mathrm{s}$ for $\mathrm{MEH}-\mathrm{PPV}^{41}$ and $\sim 10^{-5} \mathrm{~cm}^{2} / \mathrm{V} \cdot \mathrm{s}$ for P3HT, ${ }^{42}$ as determined by using the SCLC model). However, it is known that hole mobilities change when 


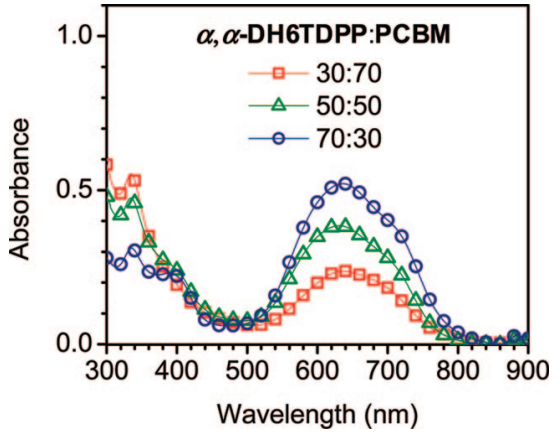

Figure 5. Absorption of blends containing $\alpha, \alpha-D H 6 T D P P$ and PCBM in various ratios, spin-coated on quartz substrates from chloroform solutions with a $2 \%(\mathrm{w} / \mathrm{v})$ total concentration.

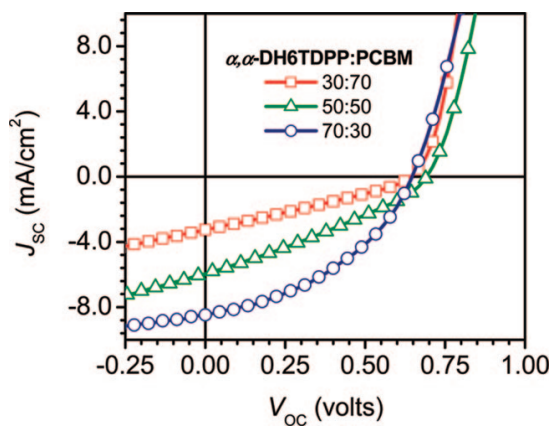

Figure 6. $J-V$ characteristics of organic solar cells prepared from $\alpha, \alpha$-DH6TDPP:PCBM blends: 30:70 (red squares), 50:50 (green triangles), and 70:30 (blue circles) under AM 1.5 irradiation $(100 \mathrm{~mW} /$ $\mathrm{cm}^{2}$ ).

mixed with PCBM, as both hole and electron mobilities depend on factors such as blend ratio and film morphology. ${ }^{43}$

Photovoltaic Properties and Film Morphology of $\alpha, \alpha-$ DH6TDPP:PCBM Blend. To demonstrate the potential of $\alpha, \alpha-$ DH6TDPP as an electron donor in photovoltaic devices, BHJ devices were fabricated by spin-coating from $2 \%(\mathrm{w} / \mathrm{v})$ chloroform solutions comprising a mixture of $\alpha, \alpha$-DH6TDPP and PCBM in different blend ratios (30:70, 50:50, and 70:30). Figure 5 shows the film absorption spectra of the various blends. It can be seen that, as the amount of PCBM decreases, the peak at $300 \mathrm{~nm}$ assigned to PCBM decreases in intensity with the simultaneous appearance of a shoulder band around $740 \mathrm{~nm}$ that was previously assigned to the aggregation of $\alpha, \alpha-$ DH6TDPP. However, the absorption band is not as intense as the one seen in the pure film probably due to disruption of the solid state packing of $\alpha, \alpha$-DH6TDPP with the addition of PCBM, as previously observed for conjugated polymers where PCBM inhibits crystallization. ${ }^{44}$

Figure 6 shows the current density versus voltage $(J-V)$ curves for devices using 30:70, 50:50, and 70:30 blend ratios under AM 1.5 simulated solar illumination at an intensity of $100 \mathrm{~mW} /$ $\mathrm{cm}^{2}$. A summary of photovoltaic properties is given in Table 1. The best devices based on 30:70 blend ratios delivered a short circuit current density of $3.13 \mathrm{~mA} / \mathrm{cm}^{2}$ and an open circuit voltage of $0.63 \mathrm{~V}$. Combined with a fill factor of 0.27 , the device gave a power conversion efficiency of $0.53 \%$. The short circuit current density increased significantly when the donor-acceptor blend ratios were changed to 50:50 and 70:30. The open circuit voltage, however, remained relatively constant. A short circuit current density of $8.42 \mathrm{~mA} / \mathrm{cm}^{2}$ and an open circuit voltage of $0.67 \mathrm{~V}$ were obtained from the device employing a 70:30 blend ratio. The power conversion efficiency of the device was calculated to be $2.33 \%$ with a fill factor of 0.45 . This power

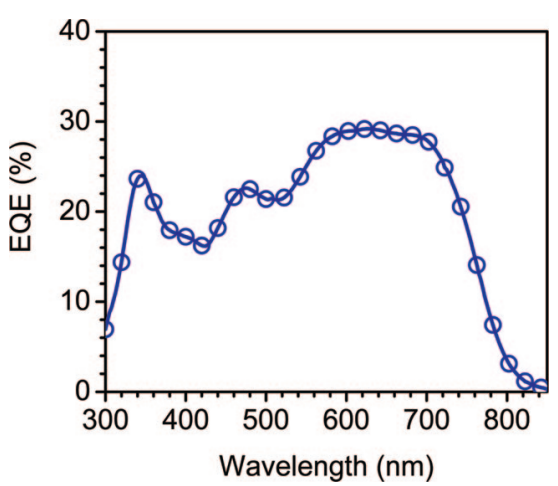

Figure 7. External quantum efficiency (EQE) curve for device using 70:30 blend of $\boldsymbol{\alpha}, \boldsymbol{\alpha}$-DH6TDPP:PCBM.

conversion efficiency value is the highest among solution processed small molecule based BHJ solar cells reported in the literature. This device exhibits external quantum efficiencies close to $25 \%$ at $343 \mathrm{~nm}$ and close to $30 \%$ between 550 and $750 \mathrm{~nm}$ (see Figure 7), the former being mainly due to the PCBM acceptor while the latter is attributed to the donor material.

It is known that the morphology of the active material in BHJ solar cells significantly affects the device performance. ${ }^{45}$ AFM topographical and phase images collected in the areas between the $\mathrm{Al}$ electrodes of the devices are shown in Figure 8. Overall, there is no micrometer-sized phase segregation occurred for the three donor/acceptor ratios used. The 30:70 $\alpha, \alpha$-DH6TDPP:PCBM film surface is very smooth, with a rms roughness of $\sim 0.45 \mathrm{~nm}$. Increasing the donor/acceptor ratio leads to increased surface roughness $(\sim 1.0 \mathrm{~nm}$ for $70: 30 \alpha, \alpha-$ DH6TDPP:PCBM film). Some degrees of intermolecular interactions of $\alpha, \alpha$-DH6TDPP are maintained in the blended film as evidenced by the fiber-like structures in the topographic and phase images (Figure 8). The devices fabricated from the 30:70 (Figure 8a,b), 50:50 (Figure 8b,c), and 70:30 (Figure 8e,f) blend ratios show minimal or no visible phase separation, but at a higher donor ratio (70:30), nanostructures can be observed from the topographic image (Figure 8e). This continuous film morphology with the absence of large phase segregation combined with the increase in absorption at longer wavelengths brought by the increase in donor concentration can account for the increase in device performance. It is also known that annealing the film before and after evaporation of the metal cathode significantly increases the device performance of BHJ solar cells. ${ }^{5 c, d, f-h}$ Annealing experiments, however, were not done with these devices, as high temperatures can lead to the removal of the $t$-Boc groups and change the chemical and electronic properties of the chromophore and the long-range molecular packing. ${ }^{36 a}$

Hole and electron mobilities are also important parameters to consider in the fabrication/function of bulk heterojunction solar cells. For optimal device performance, a balance in the mobility of both charge carriers is desirable. The hole and electron mobilities were thus measured for 30:30, 50:50, and 70:30 blend ratios using the hole-only and electron-only diode structures (Supporting Information). The mobility values were extracted using the SCLC model. It was found that the electron mobilities do not change significantly as the donor concentration increases. The electron mobilitites are 3,5 , and $6 \times 10^{-4} \mathrm{~cm}^{2} /$ Vs for $30 \%, 50 \%$, and $70 \%$ acceptor contents, respectively. In contrast, the hole mobilities exhibit a more pronounced dependence on the concentration of donor material, increasing by more than an order of magnitude from $2 \times 10^{-8}$ to $5 \times 10^{-7} \mathrm{~cm}^{2} / \mathrm{Vs}$ 

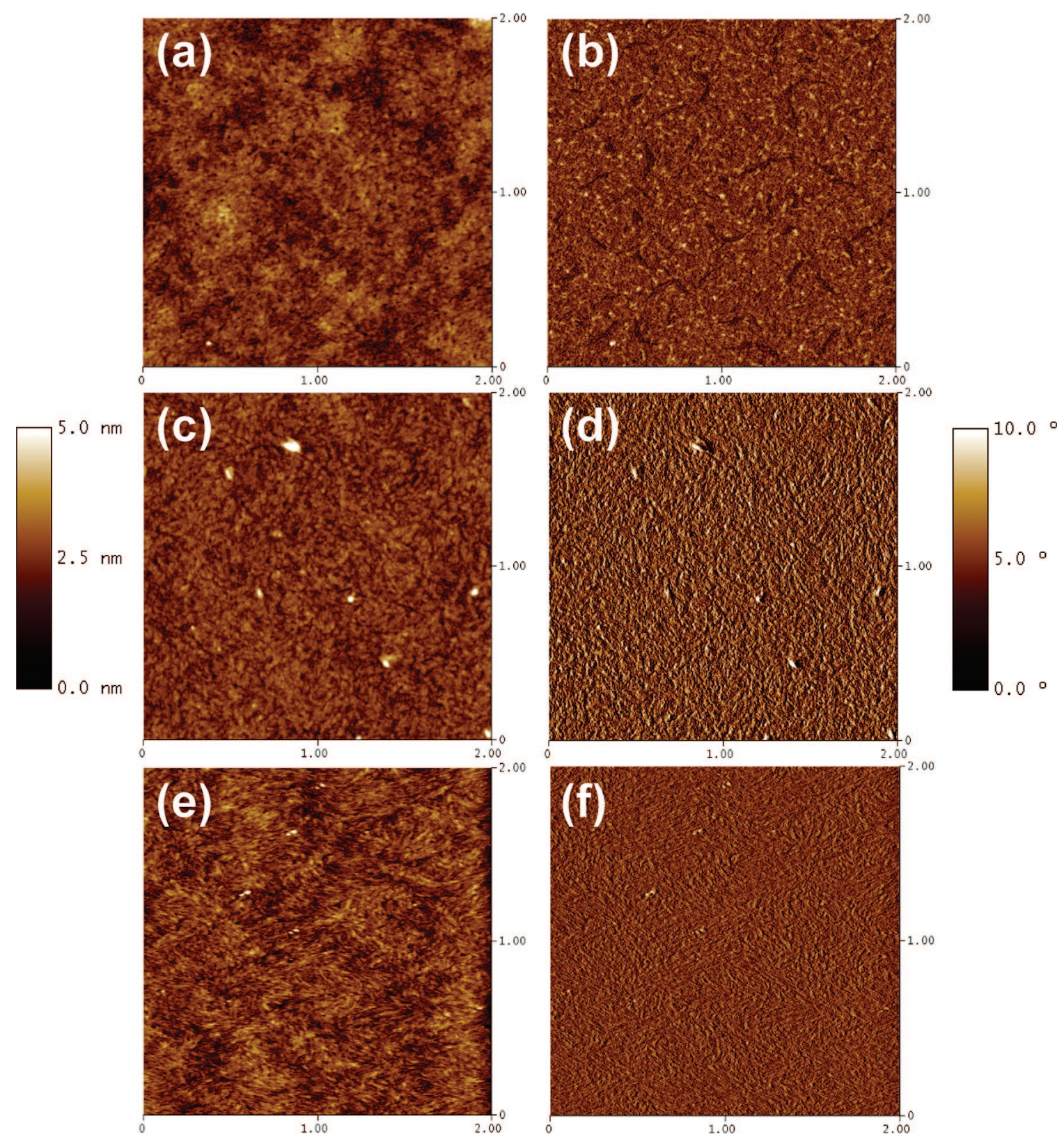

Figure 8. Tapping mode AFM topography (a, c, and e) and phase images (b, d, e, and f) of actual $\alpha, \alpha$-DH6TDPP:PCBM devices fabricated with the following ratios 30:70 (a,b), 50:50 (c,d), and 70:30 (e,f).

TABLE 1: Effect of $\alpha, \alpha-D H 6 T D P P$ and PCBM Blend Ratio on the Device Characteristics

\begin{tabular}{lcccc}
\hline $\begin{array}{c}\text { ratio } \boldsymbol{\alpha}, \boldsymbol{\alpha} \text {-DH6TDPP: } \\
\text { PCBM }\end{array}$ & $V_{\text {oc }}($ volts $)$ & $J_{\text {sc }}\left(\mathrm{mA} / \mathrm{cm}^{2}\right)$ & $\eta(\%)$ & FF \\
\hline $30: 70$ & 0.63 & 3.13 & 0.53 & 0.27 \\
$50: 50$ & 0.65 & 5.42 & 1.20 & 0.34 \\
$70: 30$ & 0.67 & 8.42 & 2.33 & 0.45
\end{tabular}

as the concentration of donor material was decreased from $30 \%$ to $70 \%$. It is evident that the charge transport properties are more balanced at high donor concentration, resulting in improved device efficiency. From these results, the electron and hole mobilities differ by 3 orders of magnitudes. Thus, higher efficiency can be achieved if one can further improve the hole mobility.

The optimal donor concentration in this system is much larger than optimal blend ratios previously observed for solutionprocessed conjugated polymer/PCBM mixtures. ${ }^{3,46}$ This may be because large concentrations of $\alpha, \alpha-D H 6 T D P P$ do not disrupt the percolation of the PCBM phase as polymers do. ${ }^{47}$ In this system, a high donor concentration is not seen to adversely affect device properties as with polymers, but allows for enhanced light absorption by the chromophore and increased order in film morphology, in addition to balancing charge transport properties.

\section{Conclusions}

We have demonstrated high efficiency, small molecule based, solution processed BHJ solar cells that incorporate an oligothiophene derivative having a diketopyrrolopyrrole core as donor material. This molecule exhibits strong absorption in the visible and near-infrared region and exhibits a hole mobility of $\sim 10^{-6}$ $\mathrm{cm}^{2} / \mathrm{V} \cdot \mathrm{s}$, as determined by the SCLC model. Solar cells using blend solutions of $\boldsymbol{\alpha}, \boldsymbol{\alpha}$-DH6TDPP with PCBM exhibit power conversion efficiencies as high as $2.33 \%$ when the donor/ acceptor ratio is 70:30 with external quantum efficiencies close to $30 \%$ between 550 and $750 \mathrm{~nm}$. Charge mobility measurements show that electron mobilities of blended films remain 
relatively constant as the donor concentration is increased while the hole mobilities increase an order of magnitude. To date, these are the best reported small molecule based solar cells fabricated by solution process. We have attributed this excellent performance to the following factors: (1) the new donor molecule $(\boldsymbol{\alpha}, \boldsymbol{\alpha}$-DH6TDPP) shows strong film absorption extending to $800 \mathrm{~nm}$, whereas other solution processed small molecules have absorption up to $700 \mathrm{~nm}$. (2) Compound $\alpha, \alpha$ DH6TDPP exhibits ordered aggregation in the solid state as evidenced by very weak photoluminescence and fiber-like structures in AFM images. (3) No large phase segregation is observed in the blends at various donor:acceptor ratios. (4) The hole mobility of $\boldsymbol{\alpha}, \boldsymbol{\alpha}$-DH6TDPP is comparable to small molecules and conjugated polymer materials used as donor materials for bulk heterojunction solar cells. (5) The absorption cross section for $\boldsymbol{\alpha}, \boldsymbol{\alpha}$-DH6TDPP is larger than for pentacene, one of the most favored candidates for use in solution processed solar cells. It is believed that further improvements in the device performance can be realized by a combination of synthesis of new derivatives and improvements in materials processing and device fabrication.

Acknowledgment. The authors thank the Office of Naval Research Young Investigator Award program and the Department of Energy for the financial support, Dr. Renqiang Yang for the NMR characterization, Dr. Xung-Dang Dung and Mananya Tantiwiwat for surface characterization, as well as Jeff Peet for helpful discussions.

Supporting Information Available: Synthetic procedures, ${ }^{1} \mathrm{H}$ NMR, mass spectrometric data, UV-vis absorption and fluorescence data, redox potentials for $\alpha, \alpha$-DH6TDPP, and current-voltage characteristics of hole-only and electron-only diodes for pure $\alpha, \alpha$-DH6TDPP and $\alpha, \alpha$-DH6TDPP:PCBM blends. This material is available free of charge via the Internet at http://pubs.acs.org.

\section{References and Notes}

(1) (a) Gunes, S.; Neugebauer, H.; Sariciftci, N. S. Chem. Rev. 2007, 107, 1324. (b) Bungaard, E.; Krebs, F. C. Sol. Energy Mater. Sol. Cells 2007, 91, 954. (c) Brabec, C. J. Sol. Energy Mater. Sol. Cells 2004, 83, 273.

(2) Scharber, M. C.; Muhlbacher, D.; Koppe, M.; Denk, P.; Waldauf, A.; Heeger, A. J.; Brabec, C. J. Adv. Mater. 2006, 18, 789.

(3) (a) Reyes-Reyes, M.; Kim, K.; Dewald, J.; Lopez-Sandoval, R.; Avadhanula, A.; Curran, S.; Caroll, D. L. Org. Lett. 2005, 7, 5749. (b) Kim, Y.; Cook, S.; Tuladhar, S. M.; Choulis, S. A.; Nelson, J.; Durrant, J. R.; Bradley, D. D. C.; Giles, M.; McCullough, I.; Ha, C.; Ree, M. Nat. Mater. 2006, 5, 197.

(4) (a) Wong, W.-Y.; Wang, X.-Z; He, Z.; Djurisic, A. B.; Yip, C.-T.; Cheung, K.-Y.; Wang, H.; Mak, C. S. K.; Chan, W.-K. Nat. Mater. 2007, 6, 521. (b) Heeney, M.; Zhang, W.; Crouch, D. J.; Chabinyc, M. L.; Gordeyev, S.; Hamilton, R.; Higgins, S. J.; McCulloch, I.; Skabara, P. J.; Sparrowe, D.; Tierney, S. Chem. Commun. 2007, 47, 5061. (c) Koppe, M.; Scharber, M.; Brabec, C.; Duffy, W.; Heeney, M.; McCulloch, I. Adv. Funct. Mater. 2007, 17, 1371. (d) Zhang, F.; Mammo, W.; Andersson, L. M.; Admassie, S.; Andersson, M. R.; Inganas, O. Adv. Mater. 2007, 18, 2169. (e) Blouin, N.; Michaud, A.; Leclerc, M. Adv. Mater. 2007, 19, 2295. (f) Zhu, Z.; Waller, D.; Gaudiana, R.; Morana, M.; Muhlbacher, D.; Scharber, M. Brabec, C. Macromolecules 2007, 40, 1981. (g) Backer, S. A.; Sivula, K.; Kavulak, D. F.; Frechet, J. M. J. Chem. Mater. 2007, 19 (12), 2927. (h) Yao, Y.; Shi, C.; Li, G.; Shrotriya, V.; Pei, Q.; Yang, Y Appl. Phys. Lett. 2006, 89, 153507/1.

(5) (a) Peet, J.; Kim, J. Y.; Coates, N. E.; Ma, W. L.; Moses, A. J.; Heeger, A.; Bazan, G. C. Nat. Mater. 2007, 6, 497. (b) Liu, S. T.; Kwok, H. S.; Djurisic, A. B. J. Phys. D: Appl. Phys. 2004, 37, 678. (c) Ko, C.-J Lin, Y.-K.; Chen, F.-C. Adv. Mater. 2007, 19, 3520. (d) Li, G.; Yao, Y.; Yang, H.; Shrotriya, V.; Yang, Y. Adv. Funct. Mater. 2007, 17, 1636. (e) Li, G.; Shrotriya, V.; Yao, Y.; Yang, Y. J. Appl. Phys. 2005, 98, 043704/1. (f) Ma, W.; Yang, C.; Gong, X.; Lee, K.-H; Heeger, A. J. Adv. Funct. Mater. 2005, 15, 1617. (g) Kim, Y.; Choulis, S.; Nelson, J.; Bradley, D. D. C.; Cook, S.; Durrant, J. R. Appl. Phys. Lett. 2005, 86, 063502/1. (h)
Savenjie, T. J.; Kroeze, J. E.; Yang, X.; Loos, J. Adv. Funct. Mater. 2005, 15, 1260. (i) Kietzke, T.; Shin, R. Y. C.; Egbe, D. A. M.; Chen, Z.-K.; Sellinger, A. Macromolecules 2007, 40, 4424.

(6) (a) Vak, D.; Kim, S.-S.; Jo, J.; Oh, S.-H.; Na, S.-I.; Kim, J.; Kim, D.-Y. Appl. Phys. Lett. 2007, 91, 081102/1. (b) Shaheen, S. E.; Radspinner, R.; Nasser, P.; Jabbour, G. E. Appl. Phys. Lett. 2001, 7, 2996. (c) Huang, J.; Li, G.; Yang, Y. Adv. Mater. 2008, published online: http:// www3.interscience.wiley.com/cgi-bin/fulltext/117881983/PDFSTART. (d) Kim, S.-S.; Na, S.-I.; Jo, J.; Tae, G.; Kim, D.-Y. Adv. Mater. 2007, 19, 4410. (e) Hoth, C. N.; Choulis, A.; Schilinsky, P.; Brabec, C. J. Adv. Mater. 2007, 19, 3973.

(7) (a) Kim, J. Y.; Lee, K.; Coates, N. E.; Moses, D.; Nguyen, T.-Q.; Dante, M.; Heeger, A. Science 2007, 317, 222. (b) Gilot, J.; Wienk, M. M.; Janssen, R. A. J. Appl. Phys. Lett. 2007, 90, 143512/1. (c) Kawano, K.; Ito, N.; Nishimori, T.; Saki, J. Appl. Phys. Lett. 2006, 88, 073514/1. (d) Li, G.; Chu, C.-W.; Shrotriya, V.; Huang, J.; Yang, Y Appl. Phys. Lett. 2006, 88, 253503/1. (e) Peiro, A. M.; Ravijaran, P.; Govender, K.; Boyle, D. S.; O'Brien, P.; Bradley, D. D. C.; Nelson, J.; Durrant, J. R. J. Mater. Chem. 2006, 16, 2088. (f) Hadipour, A.; de Boer, B.; Wildeman, J.; Kooistra, F. B.; Hummelen, J. C.; Turbiez, M. G. R.; Wienk, M. M.; Janssen, R. A. J.; Blom, P. W. M. Adv. Funct. Mater. 2006, 16, 1897. (g) Kim, J. Y.; Kim, S. H.; Lee, H.-H.; Lee, K.; Ma, W.; Gong, X.; Heeger, A. J. Adv. Mater. 2006, 18, 572. (h) Coakley, K. M.; McGeHee, M. D. Appl. Phys. Lett. 2003, 83,3380 .

(8) Schmidt-Mende, L.; Fechtenkotter, A.; Mullen, K.; Moons, E.; Friend, R. H.; Mackenzie, J. D. Science 2001, 293, 1119.

(9) Kopidakis, N.; Mithcell, W. J.; van de Lagemaat, J.; Ginley, D. S.; Rumbles, G.; Rance, W. L.; Shaheen, S. E. Appl. Phys. Lett. 2006, 89, 103524.

(10) Roncali, J.; Frere, P.; Blanchard, P.; de Bettignes, R.; Trubiez, M.; Roquest, S.; Leriche, P.; Nicolas, Y. Thin Solid Films 2006, 511, 567.

(11) Sun, X. B.; Zhou, Y. H.; Wu, W. C.; Liu, Y. Q.; Tian, W. J.; Yu, G.; Qiu, W. F.; Chen, S. Y.; Zhu, D. B. J. Phys. Chem. B 2006, 110, 7702.

(12) Roquet, S.; Cravino, A.; Leriche, P.; Aleveque, O.; Frere, P.; Roncali, J. J. Am. Chem. Soc. 2006, 128, 3459.

(13) Lloyd, M. T.; Mayer, A. C.; Subramanian, S.; Mourney, D. A.; Herman, D. J.; Bapat, A.; Anthony, J. E.; Malliaras, G. G. J. Am. Chem. Soc. 2007, 129, 9144.

(14) Valentini, L.; Bagnis, D.; Marrocchi, A.; Seri, M.; Taticchi, A.; Kenny, J. M. Chem. Mater. 2007, 20, 32.

(15) Sun, M. L; Wang, L.; Zhu, X.-H.; Du, D.; Liu, R.; Yang, W.; Cao, Y. Sol. Energy Mater. Sol. Cells. 2007, 91, 1681.

(16) He, C.; He, Q.; Yang, X.; Wu, G.; Yang, C.; Bai, F.; Shuai, Z.; Wang, L.; Li, Y. J. Phys. Chem. C 2007, 111, 8661.

(17) (a) Schulze, K.; Uhrich, C.; Schueppel, R.; Leo, K.; Pfeiffer, M.; Brier, E.; Reinold, E.; Baeuerle, P. Adv. Mater. 2006, 18, 2872. (b) Mutolo, K. L.; Mayo, E. I.; Rand, B. P.; Forrest, S. R.; Thompson, M. E. J. Am. Chem. Soc. 2006, 128, 8108. (c) Chan, M. Y.; Lai, S. L.; Fung, M. K.; Lee, C. S.; Lee, S. T. Appl. Phys. Lett. 2007, 90, 023504. (d) Peumans, P.; Uchida, S.; Forrest, S. R. Nature 2003, 425, 158.

(18) (a) Cremer, J.; Brienh, C. A. Chem. Mater. 2007, 19, 4155. (b) Cravino, A.; Leriche, P.; Aleveque, O.; Roquet, S.; Roncali, J. Adv. Mater. 2006, 18, 3033. (c) Yassar, A.; Demanze, F.; Jaafari, A.; El Idrissi, M.; Coupry, C. Adv. Funct. Mater. 2006, 12, 699. (d) Clot, O.; Selmarten, D.; McNevin, M. J. J. Mater. Chem. 2005, 15, 4934. (e) Hernandez, V.; Casado, J.; Effenberger, F.; Lopez Navarette, J. T. Synth. Met. 2001, 119, 551.

(19) (a) Xia, Y. J.; Luo, J.; Deng, X.; Li, X.; Li, D.; Zhu, X.; Yang, W.; Cao, Y. Macromol. Chem. Phys. 2006, 207, 511. (b) Yang, R.; Tian, R.; Yan, J.; Zhang, Y.; Yang, J.; Huo, Q.; Yang, W.; Zhang, C.; Cao, Y. Macromolecules 2005, 38, 244. (c) Zhou, Q.; Huo, Q.; Zheng, L.; Deng, X.; Yu, G.; Cao, Y. Appl. Phys. Lett. 2004, 85, 5081. (d) Colladet, K.; Fourier, S.; Cleji, T.; Lutsen, L.; Gelan, J.; Vanderzande, D.; Nguyen, L.H.; Neugebauer, H.; Sariciftci, S.; Aguirre, A.; Janssen, G.; Goovaerts, E. Macromolecules 2007, 40, 65. (e) Brabec, C. J.; Winder, C.; Sacriciftci, S.; Hummelen, J. C.; Dhanabalan, A.; Van Hal, P. A.; Janssen, R. A. Adv. Funct. Mater. 2002, 12, 709. (f) Persson, N.-K; Sun, M.; Kjellberg, P.; Pullerits, T.; Inganas, O J. Chem. Phys. 2005, 123, 204718/1. (g) Wang, X.; Perzon, E.; Delgado, J. L.; De la Cruz, P.; Zhang, F.; Langa, F.; Andersson, M.; Inganas, O. Appl. Phys. Lett. 2004, 85, 5081.

(20) (a) Xia, C.; Locklin, J.; Youk, J. H.; Fulghum, T.; Advincula, R. C. Langmuir 2002, 18, 955. (b) Afzali, A.; Breen, T. L.; Kagan, C. R. Chem. Mater. 2002, 14, 1742.

(21) Fachetti, A.; Yoon, M.; Di-Benedetto, S.; Marks, T. J. Polym. Prepr. 2005, 46, 591 .

(22) Mucci, A.; Parenti, F.; Schenetti, L.; Zanardi, C. Trends Heterocycl. Chem. 2001, 7, 755

(23) Tour, J. M.; Wu, R. Macromolecules 1992, 25, 1901

(24) (a) Malenfant, P. R.; Jayamaran, M.; Frechet, M. J. Chem. Mater. 1999, 11, 3420. (b) Malenfant, P. R.; Jayamaran, M.; Frechet, J. M. Polym. Mater. Sci. Eng. 1999, 80, 171. (c) Negishi, N.; Ie, Y.; Taniguchi, M.; Kawai, T.; Tada, H.; Kaneda, T.; Aso, Y. Org. Lett. 2007, 9, 829.

(25) Ellinger, S.; Ziener, U.; Ulf, T.; Lanfester, K.; Moeller, M. Chem. Mater. 2007, 19, 2070. 
(26) (a) Murphy, A.; Chang, P. C.; Van Dyke, P.; Liu, J.; Frechet, J. M. J.; Subramanian, V.; DeLongchamp, D. M.; Sambasivan, S.; Fischer, D. A.; Lin, E. L. Chem. Mater. 2005, 17, 6033. (b) Murphy, A.; Frechet, J. M. J.; Chang, P. C.; Lee, J.; Subramanian, V. J. Am. Chem. Soc. 2004, 126, 1596.

(27) (a) Ponomarenko, S. A.; Kirchmeyer, S.; Elschner, A.; Alpatova, N. M.; Halik, M.; Klauk, H.; Zschieschang, U.; Schmid, G. Chem. Mater. 2006, 18, 579. (b) Ponomarenko, S. A.; Kirchmeyer, S.; Elschner, A.; Huisman, B.; Karbarch, A.; Drechsler, D. Adv. Funct. Mater. 2003, 13, 591.

(28) (a) Zen, A.; Pingel, P.; Jaiser, F.; Neher, D.; Grenzer, J.; Juang, W.; Rabe, J.; Bilge, A.; Galbrecht, F.; Nehls, B. S.; Farrell, T.; Scherf, U.; Abellon, R. D.; Grozema, F. C.; Siebelles, L. D. A. Chem. Mater. 2007, 19, 1267. (b) Bilge, A.; Zen, A.; Forster, M.; Li, H.; Galbrecht, F.; Nehls, B. S.; Farrell, T.; Neher, D.; Scherf, U. J. Mater. Chem. 2006, 16, 3177.

(29) Farnum, D. G.; Mehta, G.; Moore, G. G.; Siegel, F. P. Tetrahedron 1974, 15, 2549.

(30) Iqbal, A.; Cassar, L.; Rochat, A. C.; Pfenninger, J. J. Coat. Technol. 1988, 60,37 .

(31) (a) Hao, Z.; Iqbal, A. Chem. Soc. Rev. 1997, 26, 203. (b) Wallquist, O.; Lenz, R. Macro. Symp. $2002,617$.

(32) Saremi, F.; Lange, G.; Tieke, B. Adv. Mater. 1996, 8, 923.

(33) (a) Behnke, M.; Tieke, B. Langmuir 2002, 18, 3815. (b) Song, B.; Wei, H.; Wang, Z.; Zhang, X.; Smet, M.; Dehaen, W. Adv. Mater. 2007, 19, 416. (c) Song, B.; Wang, S.; Zhang, X.; Fu, Y.; Smet, M.; Dehaen, W. Angew. Chem., Int. Ed. 2005, 44, 4731 .

(34) (a) Beyerlein, T.; Tieke, B.; Forero-Lenger, S.; Brutting, W. Synth. Met. 2002, 130, 115. (b) Rabindranath, A. R.; Zhu, Y.; Heim, I.; Tieke, B. Macromolecules 2006, 39, 8250. (c) Cao, D.; Liu, Q.; Zeng, W: Han, S.; Peng, J.; Liu, S. Macromolecules 2006, 39, 8437. (d) Cao, D.; Liu, Q.; Zeng, W.; Han, S.; Peng, J.; Liu, S. J. Polym. Sci., Part A 2006, 44, 2395.

(35) Tamayo, A. B., Tantiwawat, M.; Walker, B.; Nguyen, T. Q. Manuscript submitted to J. Phys. Chem. C.

(36) (a) Zambounis, J. S.; Hao, Z.; Iqbal, A. Nature 1997, 388, 131. (b) Zambounis, J. S.; Hao, Z.; Iqbal, A. US Patent No. 5,484,943, 1996. (c) Grehn, L.; Ragnarsson, U. Angew. Chem. Int. Edn. Engl. 1984, 23, 296.

(37) Langhals, H.; Potrawa, T.; Nöth, H.; Linti, G. Angew. Chem., Int Ed. Engl. 1989, 29, 478

(38) Cao, D.; Liu, Q.; Zeng, W.; Han, S.; Peng, J.; Liu, S. J. Polym. Sci., Part A: Polym. Chem. 2006, 44, 2395.

(39) (a) Gagne, R. R.; Koval, C. A.; Lisensky, G. C. Inorg. Chem. 1980, 19, 2854. (b) Sawyer, D. T.; Sobkowiak, A.; Roberts, J. L., Jr. Electrochemistry for Chemists, 2nd ed.; John Wiley and Sons: New York, 1995; p 467.

(40) (a) Blom, P. W. M.; de Jong, M. J. M.; Vleggar, J. J. M. Appl. Phys. Lett. 1996, 68, 3309. (b) Blom, P. W. M.; de Jong, M. J. M.; van Munster, M. G. Phys. Rev. B 1997, 55, 656. (c) Shen, Y.; Klein, M. W.; Jacobs, D. B.; Campbell, S. J.; Malliaras, G. G. Phys. Rev. Lett. 2001, 86, 3867. (d) Klein, M. W.; Dunlap, D. H.; Malliaras, G. G. Phys. Rev. B 2001,
64, 195332/1. (e) Savvate'ev, V. N.; Tarabia, M.; Chayet, H.; Farragi, E.Z.; Cohen, G.-B.; Kirstein, S.; Davidov, D.; Avny, Y.; Neumann, R. Synth. Met. 1997, 85, 1269.

(41) (a) Park, J. H.; Yu, H. Y.; Park, J. G.; Kim, B.; Lee, S. H.; Olofsson, L.; Persson, S. H. M.; Park, Y. W. Thin Solid Films 2001, 393, 129. (b) Tanase, C.; Wildeman, J.; Blom, P. W. M. Adv. Funct. Mater. 2005, 15, 2011. (c) Bozano, L.; Scott, J. C.; Malliaras, G. G.; Brock, P. J.; Carter, S. A. Appl. Phys. Lett. 1999, 74, 1132.

(42) (a) Tanase, C.; Meijer, E.; Blom, P. W. M.; Leeuw, D. M. Phys. Rev. Lett. 2003, 91, 216601-1. (b) Goh, C.; Kline, R. J.; Kadnikova, E. N.; Frechet, J. M. J.; McGehee, M. D. Appl. Phys. Lett. 2005, 86, 122110.

(43) (a) Andersson, L. M.; Zhang, L.; Inganas, O. Appl. Phys. Lett. 2007, 91, 071108/1. (b) Andersson, L. M.; Zhang, L.; Inganas, O. Appl. Phys. Lett. 2007, 89, 142111/1. (c) von Hauff, E.; Parisi, J.; Dyakanov, V. J. Appl. Phys. 2006, 100, 043702. (d) Jespersen, K. G.; Zhang, F.; Gadisa, A.; Sundstroem, V.; Yartsev, A.; Inganas, O. Org. Electron. 2006, 7, 235. (e) Dennler, G.; Mozer, A. J.; Juska, G.; Pivrikas, A.; Oesterbacka, R.; Fuchsbauer, A.; Sariciftci, N. S. Org. Electron. 2006, 7, 229. (f) Tuladhar, S. M.; Poplavsky, D.; Choulis, S.; Durrant, J.; Bradley, D. D. C.; Nelson, J. Adv. Funct. Mater. 2005, 15, 1171. (g) Arndt, C.; Zhokhavets, U.; Mohr, M.; Gobsch, G.; Al-Ibrahim, M.; Sensfuss, S. Synth. Met. 2004, 147, 257.

(44) Melzer, C.; Koop, E. J.; Mihailetchi, V. D.; Blom, P. W. M. Adv. Funct. Mater. 2004, 14, 865.

(45) (a) Kim, K.; Liu, J.; Namboothiry, M. A. G.; Carroll, D. Appl. Phys. Lett. 2007, 90, 163511/1. (b) Yang, X.; Loos, J. Macromolecules 2007, 40, 1353. (c) Shikler, R.; Chiesa, M.; Friend, R. H. Macromolecules 2006, 39, 5393. (d) Benanti, T. L.; Venkataraman, D. Photosynth. Res. 2006, 87, 73. (e) Hoppe, H.; Sariciftci, N. S. J. Mater. Chem. 2006, 16, 45. (f) Yang, X.; Loss, J.; Veenstra, S. C.; Verhees, W. J. H.; Wienk, M. M.; Kroon, J. M.; Michels, M. A. J.; Janssen, R. A. J. Nano Lett. 2005, 5, 579. (g) McNeil, C. R.; Frohne, H.; Holdsworth, J. L.; Dastoor, P. C. Synth. Met. 2004, 147, 101. (h) Chirvase, D.; Parisi, J.; Hummelen, J. C.; Dyakonov, V. Nanotechnology 2004, 15, 1317. (i) van Duren, J. K. J.; Yang, X.; Loos, J.; Bulle-Lieuwma, C. W. T.; Sieval, A. B.; Hummelen, J. C.; Janssen, R. A. J. Adv. Funct. Mater. 2004, 14, 425. (j) Snaith, H.; Friend, R. H. Thin Solid Films 2004, 451-452, 567. (k) Martens, T.; D'Haen, J.; Manca, J. V.; D’Olieslaeger, M.; Vanderzande, D.; De Schepper, L. Phys. Mag. 2003, 25, 199. (1) Hoppe, H.; Glatzel, T.; Niggemann, M.; Schwinger, W.; Schaeffler, F.; Hinsch, A.; Lux-Steiner, M. Ch.; Sariciftci, N. S. Thin Solid Films 2006, 511-512, 587.

(46) Mihailetchi, V. D.; Koster, L. J. A.; Blom, P. W. M.; Melzer, C.; de Boer, B.; van Duren, J. K. J.; Jannsen, R. A. J. Adv. Funct. Mater. 2005, 15,795 .

(47) van Duren, J. K. J.; Yang, X.; Loos, J.; Bulle-Lieuwma, C. W. T.; Sieval, A. B.; Hummelen, J. C.; Janssen, R. A. J. Adv. Funct. Mater. 2004, 14,425 .

\section{JP8031572}

